\title{
(5)

\section{En mann i 50-årene med nevrologiske symptomer under kreftbehandling}

NOE Å LAERE AV

\section{SIV GYDA AANES}

E-post: siv.gyda.aanes@nordlandssykehuset.no Avdeling for kreft og lindrende behandling

Nordlandssykehuset

Siv Gyda Aanes er lege i spesialisering innen onkologi.

Forfatter har fylt ut ICMJE-skjemaet og oppgir ingen interessekonflikter.

\section{CARSTEN NIEDER}

Avdeling for kreft og lindrende behandling

Nordlandssykehuset

og

Institutt for klinisk medisin

Universitetet i Troms $\varnothing$

Carsten Nieder er dr.med., spesialist i onkologi, overlege og professor II.

Forfatter har fylt ut ICMJE-skjemaet og oppgir ingen interessekonflikter.

\section{JAN PRYTZ}

Bildediagnostisk avdeling

Nordlandssykehuset

Jan Prytz er spesialist i radiologi og overlege.

Forfatter har fylt ut ICMJE-skjemaet og oppgir ingen interessekonflikter.

\section{FRANCIS ODEH}

Institutt for klinisk medisin

Universitetet i Troms $\emptyset$

og

Nevrologisk avdeling

Nordlandssykehuset

Francis Odeh er dr.med., spesialist i nevrologi, overlege og førsteamanuensis.

Forfatter har fylt ut ICMJE-skjemaet og oppgir ingen interessekonflikter.

Ved nye nevrologiske symptomer hos pasienter med kreft er det viktig å tenke differensialdiagnostisk bredt. Selve kreftsykdommen, men også behandlingen og omstendighetene rundt en alvorlig diagnose kan alle påvirke pasienten og gjøre det utfordrende å vite hva som er årsaken til endringer i helsen. Utfyllende informasjon om kliniske funn og aktuell behandling til samarbeidende spesialister kan være avgjørende for å finne riktig diagnose.

En mann i 50-årene, som fra tidligere stort sett var frisk, fikk påvist rektalkreft med spredning til lever. Etter tverrfaglig vurdering begynte han med neoadjuvant kjemoterapi i 
form av fluorouracil (5-FU), oksaliplatin og kalsiumfolinat (FLOX) før strålebehandling med god radiologisk effekt på levermetastaser. Deretter gjennomgikk pasienten en ukomplisert operasjon med rektumreseksjon og endekolostomi for å forhindre komplikasjoner fra primærsvulsten. Etter operasjonen fortsatte han med samme cellegiftbehandling, men utviklet raskt benmargstoksisitet med trombocytopeni på $84 \cdot 10^{9} / \mathrm{l}$ (referanseområde: 130-400) og nøytropeni på 1,0 $\cdot 10^{9} / 1(1,7-8,0)$ til tross for reduserte doser av cytostatika og etter hvert seponering av oksaliplatin.

Etter seks måneders behandling med cytostatika, inkludert lengre pauser mellom kurer grunnet trombocytopeni, progredierte kreftsykdommen med ytterligere spredning til lunger. Cellegiftbehandling ble endret til fluorouracil, irinotekan og bevacizumab. Etter kun én kur oppsto en ny benmargstoksisitet i form av trombocytopeni. Av den grunn ble behandlingen endret til monoterapi med irinotekan og cetuksimab, en epidermal vekstfaktorreseptorhemmer. Ved første evaluering ble det konkludert med progrediering av pasientens kreftsykdom. Radiologisk så man progrediering av levermetastaser, og biokjemisk var det stigende karsinoembryonalt antigen (CEA) fra $42 \mu \mathrm{g} / \mathrm{l}$ til $71 \mu \mathrm{g} / \mathrm{l}(<5)$ og $\emptyset \mathrm{kning}$ av leverprøver med alaninaminotransferase (ALAT) $76 \mathrm{U} / \mathrm{l}(<70)$, alkalisk fosfatase (ALP) $300 \mathrm{U} / \mathrm{l}(<105)$, gammaglutamyltransferase (GT) 860 U/l (<115), laktatdehydrogenase (LD) $400 \mathrm{U} / \mathrm{l}(<205)$ og aspartataminotransferase (ASAT) $93 \mathrm{U} / \mathrm{l}(<45)$. Dette tydet på behandlingssvikt og dårlig toleranse også etter tredjelinjebehandling. Etter en måneds behandlingspause ble det dermed startet opp med peroral regorafenib, en multikinasehemmer. Kuren ble tatt daglig i tre uker, fulgt av en ukes pause.

Ved evaluering etter to fullførte sykluser (totalt åtte uker) hadde pasienten synkende nivåer av kreftmarkøren karsinoembryonalt antigen (fra $92 \mu \mathrm{g} / \mathrm{l}$ ved oppstart til $32 \mu \mathrm{g} / \mathrm{l}(<5)$ ). Radiologisk konkluderte man med tydelig respons i lever med tilbakegang av metastaser og tilkommet nekrose. Biokjemisk så man forbedring av noen av de forhøyede lever- og galleveisprøvene (ALAT 8 o U/l, ALP 378 U/l, GT 873 U/l, LD 284 U/l og ASAT 87 U/l). Det var ingen tegn til benmargstoksisitet, som han tidligere hadde utviklet raskt under behandling. Under kurene hadde han noe plager med sårhet i munn samt tørr hud og smerter i håndflater og under fotblad.

Etter fullført tredje syklus, totalt 12 ukers behandling, kom pasienten til kreftpoliklinikken for planlagt kontroll. Han hadde siden begynnelsen av tredje syklus bemerket $ø$ kende hodepine samt vansker med å utføre dagligdagse aktiviteter. Under kuren hadde han etter hvert utviklet uttalte blemmer under fotblad og i håndflater, men disse var nå i bedring. Ifølge opplysninger fra kona var han mer oppfarende, og hun hadde også lagt merke til at han tilsynelatende ikke så maten på nedre del av tallerkenen og spiste kun det som lå $\emptyset$ verst. Han fortalte selv om $\emptyset$ kende redsel for å være alene og episoder med gråteanfall. Han anga forverring den siste uken med økende, svært intens vedvarende hodepine med ledsagende oppkast utover dagen. Det ble rekvirert CT caput grunnet mistanke om hjernemetastaser. Pasienten ble henvist for øyelegetilsyn, og kuren med regorafenib ble foreløpig stoppet.

Hjernemetastaser ved utbredt kreftsykdom kan gi symptomer som hodepine, gjerne morgenhodepine, med ledsagende kvalme og brekninger. Dette kan skyldes forhøyet intrakranialt trykk enten på grunn av masseeffekt av svulsten, ødem rundt svulsten og/eller sekundær hydrocephalusutvikling. Avhengig av tumorlokalisasjonen er fokalnevrologiske symptomer som pareser, synsfeltsutfall eller apraksi vanlig. Hjernemetastaser kan også forårsake fokale og/eller sekundært generaliserte epileptiske anfall, noen ganger som debutsymptom. Det kan ofte foreligge en uspesifikk cerebral funksjonssvekkelse med symptomer som $\varnothing \mathrm{kt}$ trettbarhet, irritabilitet, personlighetsforandringer eller psykiatriske symptomer. Metastaser i bakre skallegrop gir ofte dobbeltsyn, vertigo og koordinasjonssvikt $(1,2)$.

Ved blødning i svulsten kan symptomer utvikle seg like raskt som ved et hjerneslag (1). Hjernemetastaser er vanligere enn de primære intrakraniale svulstene og ses hyppigst ved primær kreftsykdom i lunger, dernest bryst, malignt melanom, magesekk, urinveier og genitalia, og sjeldnere ved tykk- og endetarmskreft (2). MR-undersøkelse av hjernen er den 
mest sensitive metoden for å fremstille eventuelle hjernemetastaser. De vil da som regel fremstå som runde, velavgrensede tumorer med variabelt signal avhengig av type primærtumor og eventuell nekrose. Metastasene lader vanligvis kontrast og kan være omgitt av et kraftig ødem (1).

Pasienten ble undersøkt med CT caput uten og med intravenøs kontrast. Det ble sett lavattenuasjon, som ved ødem i hvit substans oksipitalt, mest uttalt på høyre side med masseeffekt og midtlinjeforskyvning mot venstre (fig 1).

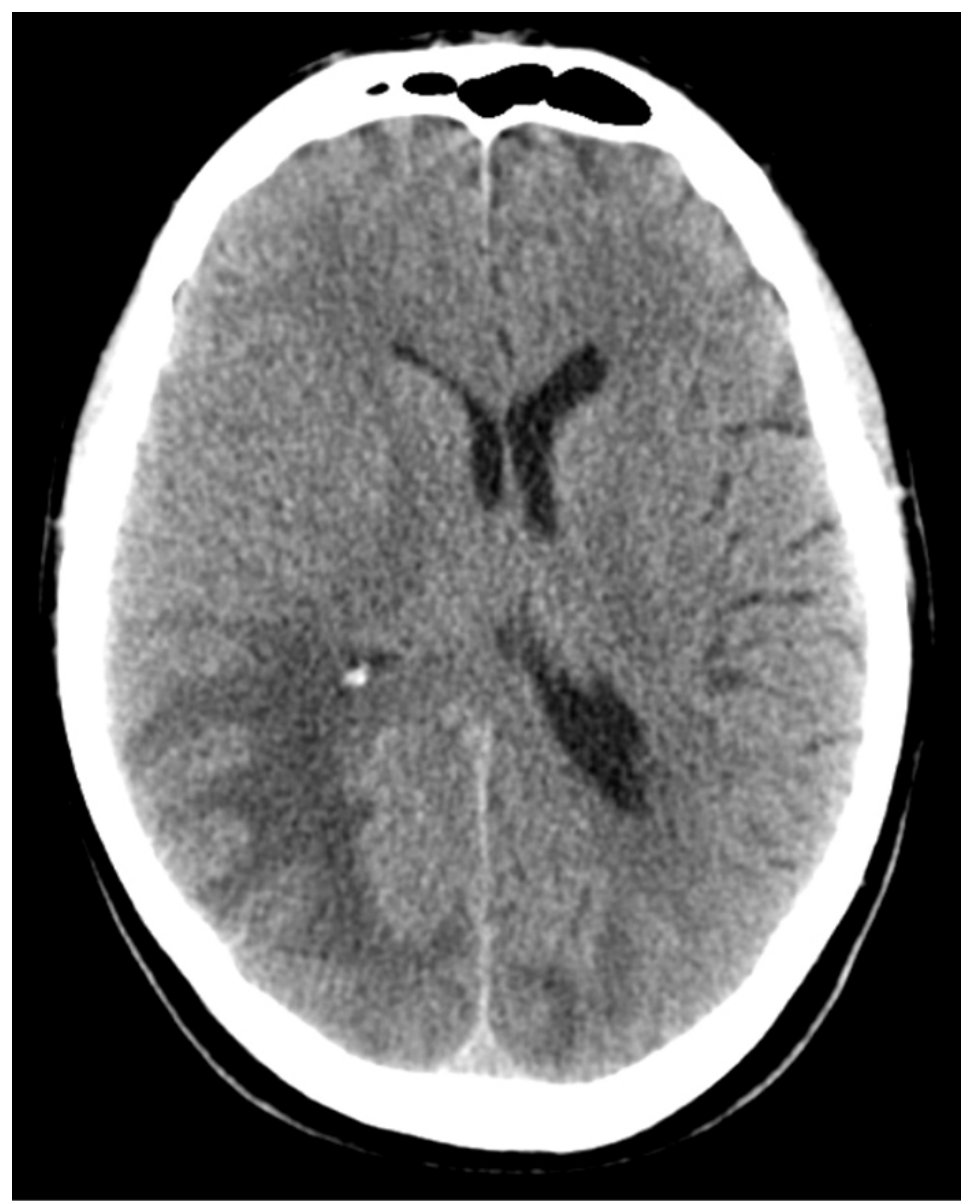

a

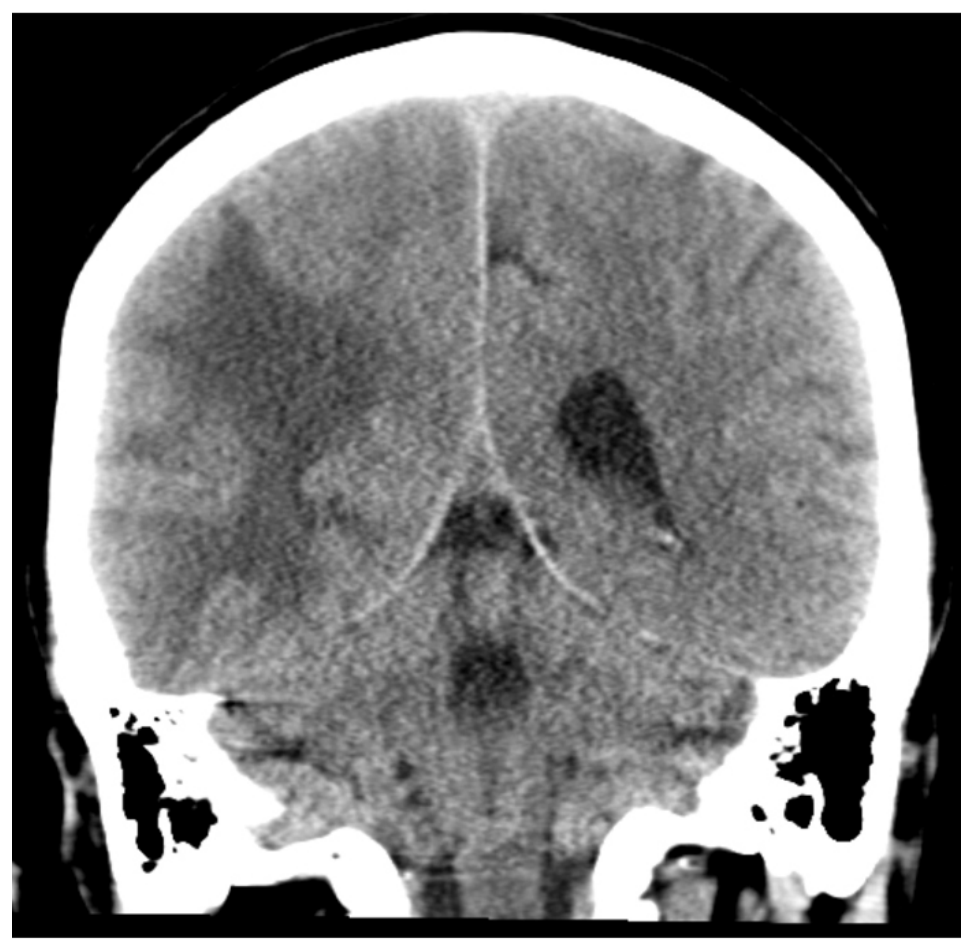

b 
Figur 1 CT caput $i$ aksialt snitt (a) og koronalt snitt (b) viser utbredte lavtetthetsforandringer oksipitotemporalt på høyre side og oksipitalt på venstre side som kan vare forenlig med ødem. Det ses ingen blødninger.

Pasienten ble innlagt på nevrologisk avdeling. Ved klinisk undersøkelse fremsto han som våken, klar og orientert for tid, sted og person. Han hadde blodtrykk på 132/88 mm Hg og regelmessig puls på $70 \mathrm{slag} / \mathrm{min}$. Han var afebril og hadde normal respirasjonsfrekvens. Ved Donders metode fant undersøkende lege innskrenket synsfelt mot venstre side, nedre kvadrant. Pasienten anga nummenhet og parestesier i fotsålene samt kuldefølelse i føttene. Det var redusert sensibilitet for berøring og stikk fra knenivå ut distalt som følge av cellegiftindusert perifer polynevropati (kjent sekvele fra tidligere cellegiftbehandling). Han hadde sidelik, normal muskelkraft i ekstremitetene, men redusert tempo og finmotoriske evner i hendene, med lett dysdiadokinesi i venstre overekstremitet. Refleksene var sidelike, med nedadvendt plantarrefleks bilateralt. Rombergs prøve viste patologi. For øvrig var det upåfallende funn ved nevrologisk og somatisk undersøkelse. Orienterende blodprøver viste trombocytopeni $106 \cdot 10^{9} / \mathrm{l}(130-400)$, senkning $28 \mathrm{~mm} / \mathrm{t}(<20)$, CRP $39 \mathrm{mg} / \mathrm{l}(<5)$, ALP $353 \mathrm{U} / \mathrm{l}$ (<105), GT $661 \mathrm{U} / \mathrm{l}$ (<115), LD $269 \mathrm{U} / \mathrm{l}(<205)$ og CEA $49 \mu \mathrm{g} / \mathrm{l}(<5)$. Ellers var det upåfallende funn i blodprøver, inkludert differensialtelling av leukocytter.

Ved øyelegeundersøkelse ble det konkludert med homonym kvadrantanopsi (synsfeltsutfall i begge nedre venstre kvadranter), ellers normale funn. På bakgrunn av uttalte trykksymptomer og påvist hjerneødem på CT mistenkte man primært hjernemetastaser, og det ble derfor startet behandling med høydose perorale kortikosteroider. Pasienten ble henvist til MR caput grunnet fortsatt mistanke om hjernemetastaser.

Allerede dagen etter innleggelsen var pasienten i klinisk bedring og fikk dra hjem på permisjon i påvente av MR-undersøkelse. Ergoterapeut utførte kognitiv testing med Trandex-skår, der pasienten skåret 46/6o poeng med trekk for orientering, hukommelse, konsentrasjon og abstrakt tenkning. Dette tydet på en lett kognitiv svik.

MR caput med intravenøs kontrast (fig 2) viste økt signal i hvit substans i høyre temporalog oksipitalregion samt i mediale venstre oksipitalregion ved T2-vekting og FLAIRsekvenser. Det var ingen restriksjon på diffusjonsvektet serie (vanlig ved hjerneinfarkt, abscess og i svulster), men økt ADC-verdi (apparent diffusion coefficient). Dette tydet på økt vanninnhold i hjernevevet, best forenlig med et vasogent $\emptyset$ dem. Det var ingen patologisk kontrastoppladning eller kontrastladende lesjoner, noe som talte mot metastaser, abscess eller primær hjernesvulst, men man så tallrike punktformige blødninger i cortex i de aktuelle områdene på suceptibilitetsvektet sekvens. MR-spektroskopi viste normal metabolittfordeling, som også talte mot tumor.
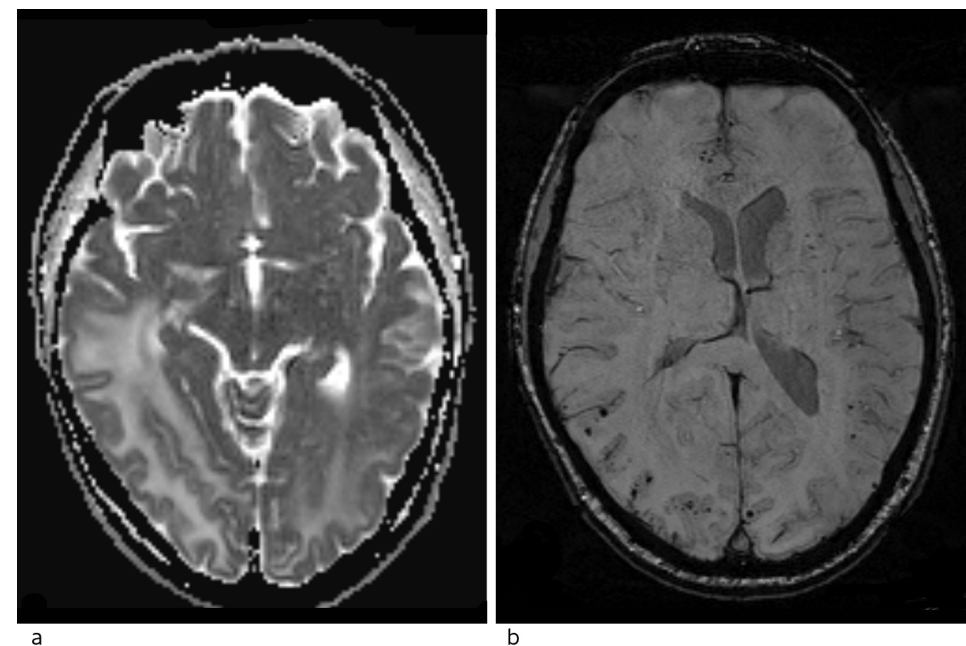

Figur 2 MR caput. a) ADC-kart fra diffusjon viser høye verdier forenlig med vasogent ødem. $b$ ) Suceptibilitetsvektede sekvenser(SWI) viser tallrike, punktformige lesjoner med svcert lavt signal forenlig med mikroblødninger spredt $i$ cortex i begge hemisfarer, med overvekt oksipitalt på høyre side. 
Differensialdiagnostisk kunne dette være forenlig med gliomatosis cerebri, progressiv multifokal leukoencefalopati (PML) eller posterior reversibel encefalopati-syndrom (PRES). Gliomatosis cerebri er en ekstremt sjelden hjernesvulst som utgår fra astrocytter. Karakteristisk vokser denne diffust i hvit substans og affiserer minst tre lapper. Vanligvis presenterer denne svulsten et fredelig klinisk bilde, mens det radiologisk sett er en omfattende lesjon (3).

Progressiv multifokal leukoencefalopati er en demyeliniserende sykdom i hjernen forårsaket av reaktivering av latent John Cunningham-virus (JCV, et humant polyomavirus) hos immunkompromitterte pasienter (4). Tilstanden kan gi subakutte nevrologiske symptomer som kognitive vansker, motoriske symptomer som hemi- eller monoparese, ataksi samt synsforstyrrelser som hemianopsi og diplopi (4). Vår pasient kunne ha vært immunsupprimert som følge av behandlingen med regorafenib og også som følge av tidligere cellegiftbehandling, men hadde ingen leukopeni ved innleggelse og hadde ved kontrollene heller ikke vært immunsupprimert under behandlingen med regorafenib.

Polymerasekjedereaksjonstest (PCR) var negativ for John Cunningham-virus. Det gjorde progressiv multifokal leukoencefalopati mindre sannsynlig.

Ut fra sykehistorien, sykdomsforløpet og MR-funn med vasogent ødem og multiple kortikale småblødninger i oksipitalregionene, vurderte vi at diagnosen posterior reversibel encefalopati-syndrom var mest sannsynlig, forårsaket av tumorrettet behandling med regorafenib.

Regorafenib og kortikosteroidbehandling ble seponert, og pasienten opplevde spontan og rask bedring med tilbakegang av hodepine, normalisering av synsfelt, tempo og balanse uten ytterligere tiltak. Ved poliklinisk kontroll en måned senere hadde han full restitusjon av sine nevrologiske symptomer, med normal klinisk status. MR caput viste betydelig tilbakegang av lesjonene. CT caput tatt etter tre måneder viste fortsatt beskjedne restforandringer rundt bakre horn av høyre sideventrikkel og tilbakegang av midtlinjeforskyvning. Pasienten syntes da han hadde noe mer vansker med hukommelsen, og klinisk, biokjemisk og radiologisk var det tegn til progrediering av kreftsykdommen. Han døde av kreftsykdom tre måneder senere.

\section{Diskusjon}

Posterior reversibel encefalopati-syndrom er et oftest reversibelt syndrom som kan oppdages radiologisk. Forekomsten er ukjent, men tilstanden vurderes å være underdiagnostisert. Den rammer alle aldersgrupper, 2-9o-årsalder, og oppfattes å ha en høyere utbredelse hos kvinner på grunn av sin tilknytning til preeklampsi, selv om dette ikke er publisert (5). Posterior reversibel encefalopati-syndrom er tidligere beskrevet i Tidsskriftet hos et barn med kramper og plutselig synstap under cellegiftbehandling (6). Klinisk kan tilstanden presentere seg med en rekke nevrologiske manifestasjoner, vanligvis med en (sub)akutt debut som strekker seg fra timer til uker. Presenterende symptomer er ofte uspesifikke, med kognitive forstyrrelser, forvirring, bevissthetsreduksjon, hodepine, synsutfall og krampeanfall som de vanligste symptomene. Ved alvorlige tilfeller kan tilstanden føre til koma og død (7).

Radiologisk er syndromet preget av karakteristiske funn med ødem i hvit substans, oftest i bakre (parieto-oksipitale) deler av hjernen (5). I motsetning til bilaterale bakre infarkter, er oftest calcarine og paramediane deler av oksipitallappen uten ødem. MR spiller en viktig diagnostisk rolle (8), da lesjonene har økt signal på MR-bilder med T2-vekting og FLAIRkontrast. Vanligvis har disse lesjonene en høy ADC-verdi på diffusjonssekvensen, en indikator på vasogent $\emptyset$ dem og dermed reversibilitet og bedre prognose $(9,10)$. Bruk av suceptibilitetsvektede sekvenser (SWI, en forholdsvis ny metode) har vist at mikroblødninger er vanlig i affiserte områder hos pasienter med posterior reversibel encefalopati-syndrom, hovedsakelig i cortex, men også i hvit substans (8).

Det er omdiskutert hvorvidt navnet er beskrivende for de kliniske og nevroradiologiske 
karakteristika. Etter at tilstanden først ble beskrevet i 1996 (5), er det blitt rapportert flere kasuistikker som viser at tilstanden ikke alltid er reversibel og at forandringene ikke alltid er lokalisert til hvit substans eller de bakre deler av hjernen (11-13).

Posterior reversibel encefalopati-syndrom assosieres med stadig flere medisinske tilstander hvor den kan opptre som en komplikasjon. Vanligste tilstander er hypertensjon, (pre)eklampsi, nyresvikt, sepsis og autoimmune sykdommer. Syndromet kan også opptre direkte under behandling med immunmodulerende og cytotoksiske medikamenter. Tilstanden er en sjelden komplikasjon av angiogenesehemmerbehandling, men er dokumentert ved behandling med sorafenib, sunitinib og pazopanib. Regorafenibassosiert posterior reversibel encefalopati-syndrom er imidlertid kun publisert i ett tilfelle tidligere (14).

Regorafenib hemmer proteinkinaser involvert i tumorangiogenese, onkogenese , metastasering og tumorimmunitet (15). Indikasjonen er metastasert kolorektalkreft, der pasienten tidligere er behandlet med fluorpyrimidinbasert kjemoterapi uten tilfredsstillende effekt. I nasjonale retningslinjer for tykk- og endetarmskreft er midlet godkjent til bruk i tredjelinjebehandling hos pasienter med god allmenntilstand. Det har vist å øke median overlevelse med 1,4 måneder sammenlignet med placebo og anbefales ikke brukt rutinemessig på grunn av begrenset nytteverdi (16).

Patogenesen ved posterior reversibel encefalopati-syndrom er ennå uklar, men antatt mekanisme er endotelial dysfunksjon etter direkte toksisk virkning på vaskulært endotel (8). I de tilfellene hvor pasientene har høyt blodtrykk og utvikler tilstanden, kan årsaken være blodtrykksøkning ut over det den cerebrale autoreguleringen greier å håndtere. Man tror her at et høyt cerebralt perfusjonstrykk med påfølgende skade på blod-hjerne-barrieren kan gi vasodilatasjon og hyperperfusjon med påfølgende vaskulær lekkasje og hjerneødem (17). Hos vår pasient var det høyeste målte blodtrykket 149/91 mm Hg, og dermed var det mindre sannsynlig at hypertensjon skulle være årsak her. Per i dag er det ingen konsensus for spesifikk behandling av posterior reversibel encefalopati-syndrom, kun symptomatisk tilnærming. Tidlig identifisering og behandling av underliggende årsak til tilstanden vektlegges for å unngå komplikasjoner og varige nevrologiske utfall, i verste fall dødsfall grunnet utvikling av cytotoksisk ødem, blødninger og iskemi $(8,10)$.

I mange tilfeller av posterior reversibel encefalopati-syndrom er immunsuppressive eller cytotoksiske medikamenter identifisert som årsak til de nevrologiske manifestasjonene. Behandlingsstrategi er derfor å seponere denne behandlingen. Imidlertid er det omdiskutert om nedtrapping eller umiddelbar seponering av utløsende preparat er nødvendig, eller om dosereduksjon kan være tilstrekkelig $(18,19)$. Det er heller ingen konsensus om terapeutisk tilnærming etter at de nevrologiske symptomer har avtatt, men tilbakefall anses å forekomme meget sjelden. Prognosen er god, oftest med normalisering i løpet av noen få dager til uker.

\section{LITTERATUR:}

1. Khasraw M, Posner JB. Neurological complications of systemic cancer. Lancet Neurol 2010; 9: 1214 - 27. [PubMed][CrossRef]

2. Christensen TD, Spindler KL, Palshof JA et al. Systematic review: brain metastases from colorectal cancer-Incidence and patient characteristics. BMC Cancer 2016; 16: 26o. [PubMed][CrossRef]

3. Rudà R, Bertero L, Sanson M. Gliomatosis cerebri: a review. Curr Treat Options Neurol 2014; 16: 273. [PubMed][CrossRef]

4. Tan CS, Koralnik IJ. Progressive multifocal leukoencephalopathy and other disorders caused by JC virus: clinical features and pathogenesis. Lancet Neurol 2010; 9: 425-37. [PubMed][CrossRef]

5. Hinchey J, Chaves C, Appignani B et al. A reversible posterior leukoencephalopathy syndrome. N Engl J Med 1996; 334: 494 - 500. [PubMed][CrossRef] 
6. Mjelle AB, Donner EM, Berg A. Et barn med kramper og plutselig synstap under cellegiftbehandling. Tidsskr Nor Legeforen 2015; 135: 441 - 4. [PubMed][CrossRef]

7. Lee VH, Wijdicks EF, Manno EM et al. Clinical spectrum of reversible posterior leukoencephalopathy syndrome. Arch Neurol 2008; 65: 205-10. [PubMed]

8. Fugate JE, Rabinstein AA. Posterior reversible encephalopathy syndrome: clinical and radiological manifestations, pathophysiology, and outstanding questions. Lancet Neurol 2015; 14: 914 - 25. [PubMed][CrossRef]

9. Bartynski WS, Boardman JF. Distinct imaging patterns and lesion distribution in posterior reversible encephalopathy syndrome. AJNR Am J Neuroradiol 2007; 28:1320 - 7. [PubMed][CrossRef]

10. Covarrubias DJ, Luetmer PH, Campeau NG. Posterior reversible encephalopathy syndrome: prognostic utility of quantitative diffusion-weighted MR images. AJNR Am J Neuroradiol 2002; 23: 1038 - 48. [PubMed]

11. Antunes NL, Small TN, George D et al. Posterior leukoencephalopathy syndrome may not be reversible. Pediatr Neurol 1999; 20: 241 - 3. [PubMed][CrossRef]

12. Casey SO, Sampaio RC, Michel E et al. Posterior reversible encephalopathy syndrome: utility of fluid-attenuated inversion recovery MR imaging in the detection of cortical and subcortical lesions. AJNR Am J Neuroradiol 200o; 21: 1199 - 206. [PubMed]

13. Narbone MC, Musolino R, Granata F et al. PRES: posterior or potentially reversible encephalopathy syndrome? Neurol Sci 2006; 27: 187 - 9. [PubMed][CrossRef]

14. Myint ZW, Sen JM, Watts NL et al. Reversible posterior leukoencephalopathy syndrome during regorafenib treatment: a case report and literature review of reversible posterior leukoencephalopathy syndrome associated with multikinase inhibitors. Clin Colorectal Cancer 2014; 13: 127 -30. [PubMed][CrossRef]

15. Crona DJ, Keisler MD, Walko CM. Regorafenib: a novel multitargeted tyrosine kinase inhibitor for colorectal cancer and gastrointestinal stromal tumors. Ann Pharmacother 2013; 47: 1685 - 96. [PubMed][CrossRef]

16. Grothey A, Van Cutsem E, Sobrero A et al. Regorafenib monotherapy for previously treated metastatic colorectal cancer (CORRECT): an international, multicentre, randomised, placebocontrolled, phase 3 trial. Lancet 2013;381:303-12. [PubMed][CrossRef]

17. Bartynski WS. Posterior reversible encephalopathy syndrome, part 2: controversies surrounding pathophysiology of vasogenic edema. AJNR Am J Neuroradiol 2008; 29: 1043 - 9. [PubMed][CrossRef]

18. Hammerstrom AE, Howell J, Gulbis A et al. Tacrolimus-associated posterior reversible encephalopathy syndrome in hematopoietic allogeneic stem cell transplantation. Am J Hematol 2013; 88:301 - 5. [PubMed][CrossRef]

19. Singer S, Grommes C, Reiner AS et al. Posterior reversible encephalopathy syndrome in patients with cancer. Oncologist 2015; 20: 806 - 11. [PubMed][CrossRef]

Publisert: 23. oktober 2018. Tidsskr Nor Legeforen. DOI: 10.4045/tidsskr.18.0096

Mottatt 25.1.2018, første revisjon innsendt 8.6.2018, godkjent 27.8.2018.

(C) Tidsskrift for Den norske legeforening 2020. Lastet ned fra tidsskriftet.no 